DOI https://doi.org/10.30525/978-9934-26-114-5-43

\title{
КРИТЕРІЇ ВИЗНАЧЕННЯ РІВНЯ ІНФОРМАЦИЙНОЇ КУЛЬТУРИ МАЙБУТНІХ УЧИТЕЛІВ ІСТОРІЇ: ТЕОРЕТИЧНИЙ АСПЕКТ
}

\author{
Яцій О. М. \\ кандидат педагогічних наук, \\ доиент кафедри педагогіки \\ Державний заклад «Південноукраӥнський наиіональний педагогічний \\ університет імені К. Д. Уиинського» \\ м. Одеса, Україна
}

Стрімко зросла наукоємність педагогічної праці, сучасний історик працює $з$ великими потоками інформації. Інформаційному суспільству необхідний новий тип вчителя історії, педагога, готового до життя i професійної діяльності в інформаційному суспільстві - особистість, яка володіє виховним творчим потенціалом, не тільки сукупністю історичних знань, сукупністю знань, умінь і навичок з пошуку, аналізу i використання інформації, культурою використання засобів інформатизації як джерела інформації, отримання і здобування знань, здібна до професійного саморозвитку та самоосвіти і критичного сприйняття потоку інформації, що все збільшується. Тільки така особистість може впливати на формування історичної самосвідомості свого народу. У зв'язку з цим неодмінною ознакою високого професіоналізму майбутнього вчителя історії виступає інформаційна культура та історична самосвідомість.

Проблема формування інформаційної культури представлена у наукових дослідженнях І. Беха, М. Бухаркиної, Г. Вишинської, Г. Воробйова, М. Вохришевої, С. Гончаренко, А. Гречихіна, В. Дмитрієвої, Н. Зинов’євої, М. Жалдака, В. Матросова, Е. Медведєвої, Н. Морзе, Н. Непомнящеї, К. Овчинникової, О. Петрова, Є. Полат, А. Старєвої та інших вчених. Разом з тим, аналіз наукової літератури засвідчує, що дослідники мало приділяють увагу формуванню інформаційної культури студентів істориків - більше студентів фізикоматематичних факультетів, лінгвістів, студентів-журналістів, економістів. Проблема формування інформаційної культури майбутніх учителів історії залишилася поза увагою дослідників.

Мета дослідження полягає у розробці критеріїв формування інформаційної культури майбутніх учителів історії, показників визначення іiі рівня. 
Діагностичний експеримент проходив останні три роки на других та четвертих курсах історико-філософського відділення соціальногуманітарного факультету Південноукраїнського державного педагогічного університету імені К.Д. Ушинського 80 студентів та історичного факультету Одеського національного університету імені I.I. Мечникова 30 студентів. В експерименті брали участь 110 студентів другого, третього і четвертого курсів означених факультетів. Експериментальна робота зі студентами проводилась у чотири етапи - аналіз програм підготовки бакалаврів, визначення головних компетентностей та компетенцій якими вони повинні оволодіти; розробка критеріїв та показників інформаційної культури майбутнього вчителя історії; розробка методики діагностичного експерименту та його проведення; порівняльний аналіз отриманих даних.

3 метою встановлення рівня сформованості інформаційної культури студентів під час дослідницької роботи були виділені критерії і їх показники, за якими можна судити про рівень сформованості того чи іншого компонента інформаційної культури студентів істориків. Так, відповідно до компонентів інформаційної культури майбутнього вчителя історії були встановлені такі критерії іiі сформованості і їх показники:

1. Ціннісно-змістовий з показниками двох видів (інформаційний та історичний):

- інформаційна обізнаність (обізнаність студентів 3 основними поняттями інформаційної культури, а також з методами, формами i прийомами застосування нових інформаційних технологій, різних комунікаційних програм у навчальному процесі, проблемами дистанційного навчання);

- історична обізнаність (ключові поняття історичної науки, філософії історії, методики навчання історії, історичний тезаурус)

- інформаційна активність (процес - мотивування і самомотивування, розвиненість (і якість) інформаційних потреб, інтересів і дослідницьких навичок особистості.

- інформаційна готовність (культура спілкування, навички комунікації, відношення до розвитку інформаційної культури, адекватна самооцінка, позитивні емоції і поведінка особистості в інформаційному середовищі, усталеність і відповідальність, культура етикету, достатній рівень історичної самосвідомості).

2. Професійно-діяльнісний критерій з показниками:

- вміння, спрямовані на отримання достовірної інформації та знань з різноманітних джерел; 
- володіння методологією і методикою роботи 3 історичними джерелами;

- вміння, спрямовані на інтерпретацію та аналіз інформації;

- вміння, спрямовані на адекватну передачу інформації.

3. Творчо-рефлексійний критерій з показниками:

- здатність до різних форм проєктування та креативного мислення, створення нового інформаційного продукту;

- здатність до самостійного мислення, логічність висновків, інтелектуальна активність, уміння формулювати стратегічні, тактичні, оперативні завдання, пошукова діяльність;

- здатність до самоаналізу та самооцінки (контроль в процесі діяльності досягнень та цілей, розуміння внутрішніх і зовнішніх умов та змін, суб'єктність інформаційної діяльності і відносин, здатність до самоконтролю та самокорекції).

Відповідно до зазначених критеріїв у рамках кожного були визначені загальні рівні сформованості інформаційної культури: високий (креативно-професійний), достатній (професійний), середній (пошуково-пізнавальний), низький.

Охарактеризуємо суть рівневої характеристики сформованості інформаційної культури в майбутніх учителів історії.

Високий (креативно-професійний) рівень розвитку інформаційної культури відрізняється високим рівнем історичної свідомості, знанням філософії історії, осмисленням інформаційних цінностей, високим рівнем самоосвіти, інтелектуальною активністю, усталеними потребами та мотивами. Студенти високого рівня сформованості інформаційної культури багато читають, вміють моделювати різні соціальні ситуації та їх вирішення, у них високий рівень аксіологічної культури i гуманістичних цінностей. Мають гнучке мислення, високий рівень рефлексії, індивідуально-творчий стиль у спілкуванні. Володіють навичками інформаційної діяльності, усвідомлюють потребу у повній реалізації своїх здібностей і інтересів в інформаційній сфері. Вміють самостійно здобувати нові необхідні знання. Мають досвід в розробці певних проєктів, працюють добре і в нестандартних ситуаціях. Володіють методологією і методикою роботи 3 історичними джерелами.

Достатній (професійний) рівень розвитку інформаційної культури відрізняється високим рівнем історичної свідомості, осмисленням інформаційних цінностей, високим рівнем самоосвіти, інтелектуальною активністю, усталеними потребами та мотивами. Студенти достатнього рівня сформованості інформаційної культури вміють моделювати різні соціальні ситуації та їх вирішення, у них високий рівень аксіологічної 172 
культури i гуманістичних цінностей. Мають гнучке мислення, достатній рівень самоаналізу адекватно самооцінюють свої досягнення. Володіють навичками інформаційної діяльності. Вміють самостійно здобувати нові необхідні знання. Добре працюють в стандартних ситуаціях. Володіють методикою роботи з історичними джерелами.

Середній рівень (пошуковий-пізнавальний) - заснований на розвитку інформаційної активності. Студенти часто потребують стимулювання їх активності з боку викладачів. Вони можуть багато навіть читати але безсистемно. Студенти середнього рівня інформаційної культури інколи неадекватно оцінюють свої досягнення. Здатні вирішувати лише стандартні педагогічні завдання. Самостійність продукованих думок недостатньо аргументована. Мають невеликий досвід у вирішенні різних інформаційно-ситуаційних завдань. Вони хоча i зацікавленні в отриманні інформаційних знань і вмінь - дуже повільно їх засвоюють. Середній рівень пов'язаний з розвитком інформаційної мотивації і усвідомленням власних інформаційних потреб. Частково володіють методикою роботи з історичними джерелами.

Низький - репродуктивний рівень, базується на низькій мотивації та невеликому соціальному досвіді. У студентів ще не сформована усталена система інформаційних навичок. Більшість 3 них мало читають. Потреба в самоосвіті не усталена. Для цього рівня головною особливістю є стимулювання розвитку системи знань, умінь і навичок 3 боку викладачів вишів. Для більшості студентів цього рівня сформованості інформаційної культури властиві репродуктивний характер засвоєння інформаційних знань, стереотипність мислення, виконання навчальних дій за зразком, низький пізнавальний інтерес, пасивність у ситуаціях інформаційної взаємодії.

Розроблені критерії дають можливість діагностувати рівень інформаційної культури майбутніх учителів історії.

\section{Література:}

1. Гончаренко С.Ю. Український педагогічний словник. К.: Либідь, 1997. 376 с.

2. Непомнящая Н.И. Психодиагностика личности. М.: Владос, 2003. 192 c.

3. Новые педагогические и информационные технологи в системе образования:Учебное пособие/ Е.С. Полат, М.Ю. Бухаркина, М.В. Моисеева, А.Е. Петров. М.: Академия, 2003. 272 с.

4. Старєва А.М. Методика навчання історії: особистісно орієнтований підхід: Навчальний посібник. Миколаїв: Вид-во «Іліон», 2007. 332 c. 